Leibniz read eagorly all the mathematical works he could obtain, and endeavoured to unify the solutions of particular problems into a general method, such as that which he devised for the summation of series.

In 1673 Leibniz spent about three months in London and attended a meeting of the Royal Society, the secretary of which, Oldenburg, was a countryman of his and had corresponded with him since 1670. Leibniz was informed by Pell that the method of summation of series had already been discovered by Regnauld and published in a book by Mouton. Thus Leibniz's lack of knowledge of current mathematical literature exposed him to a suspicion of plagiarism. On his return to Paris, Leibniz made great progress. By 1675 he had developed the symbolism and most of the elementary rules of the differential and integral calculus. Newton's fluxions had been discovered about ten years previously ; but this was known only to a few friends. Dr. Hofmann gives in considerable detail the development of Leibniz's form of calculus and holds strongly that it was quite independent of the work of Newton. But he also shows how several incidents, long before the unhappy controversy over the invention of the calculus, gave rise to suspicions of plagiarism.

In 1676 a letter prepared by Collins and corrected by Newton was sent by Oldenburg to Leibniz, and gave, among other results, infinite series for logarithmic and trigonometrical functions. After only a hasty reading of this letter, Leibniz sent back a prompt answer containing what he considered his own discoveries on the subject. However, these were really essentially the same as Newton's own series. Certainly they were derived in a different way; but this was not made sufficiently clear. When the letter, addressed to Oldenburg, finally reached Newton, some time had elapsed, and Newton imagined that the letter was a carefully prepared attempt at plagiarism. On another occasion, on his second visit to England, Leibniz displayed great anxiety to read and copy the manuscripts of Newton and others entrusted to Collins, and suspicion was again aroused. Dr. Hofmann deals with these incidents very fully and concludes that Leibniz's actions were really quite innocent. However, we cannot help feeling that all this was creating an atmosphere which was destined afterwards to become poisonous.

It is not certain that Dr. Hofmann's views on controversial questions will be universally accepted; but all will be interested in the study of the evidence he produces.

H. T. H. Piaggio

\section{FARMING IN BRITAIN THROUGH THE AGES}

A History of English Farming

By Dr. C. S. Orwin. (Nelson's Agricultural Series.) Pp. vii $+152+24$ plates. (London and Edinburgh : Thomas Nelson and Sons, Ltd., 1949.) 8s. 6d. net.

TT is widely recognized that no one can get far in 1 the study of any subject without some knowledge of its history. This is emphatically true of agriculture, where breaks are scarce and where most things can be traced back to something that has gone before. Agriculturists fortunately possess a great classic in Lord Ernle's "English Farming, Past and Present"; but there has always been felt the need for some smaller book that would give the student a general picture in which the perspective is sound and the details, so far as they are given, accurate. Dr. C. S. Orwin's book supplies this need; in less than 150 pages he presents an account of English farm history which experts will read with pleasure and students will find most helpful.

Agriculture has been practised in Great Britain for some four thousand years; the Neolithic peoples were the first farmers, and something of their methods is now being gleaned by archæologists. By Roman times there were already tools and implements which, as Dr. Orwin says, "might be used without arousing comment by a farm worker today". Before the Norman Conquest the open-field system had developed, and of this, as might be expected, the account is full and lucid. The Black Death of 1349 intensified a change that had already begun, namely, the break-up of the old feudal system and the beginnings of independent farms, which heralded the change from subsistence farming to farming for profit with the aid of paid workers, and necessitated the enclosure of the old open fields and the consequent reduction in numbers of those having rights in land use. These changes are clearly set forth.

Then follows a section on farming in competition, showing the effects of the agricultural development of the new countries on British agriculture. The author discusses the three partners in farming : the farm worker, the farmer and the land owner. Here there is room for much controversy, but Dr. Orwin maintains a sound balance and sets out the facts clearly. He gives some remarkable instances of men who, starting in a comparatively small way, rose to very large-scale farming; such men were George Baylis, who began with 350 acres and ended up with twelve thousand acres, and Samuel Farmer, whose father had farmed 1,500 acres and who at the height of his activity was farming with his partners some twenty-five thousand acres and ended with a fortune of nearly half a million pounds. But not everyone can hope for such successes, and Dr. Orwin is somewhat pessimistic-perhaps unduly so-about farming as a career for men without capital.

Of the three partners, the land owner is nowadays probably the most handicapped in trying to discharge his duties, and some readers will think that Dr. Orwin has not given sufficient credit to the country squires for the great part they have played, and still oould play but for crippling taxation, in the life of the countryside. But all who know anything about the subject will agree with his concluding sentences : "political action by the State ... continued indefinitely can only stereotype and even sterilize the industry. History will show . . . that the advance. ment of agriculture is linked by unbreakable bonds with progress in the education of the farmer and research into the problems of his art." Work on these lines has been quietly going on now for some fifty years; Dr. Orwin mentions A. D. Hall, but in a future edition it is to be hoped that he will give some account of the work of the other great pioneers - T. B. Wood, Rowland Biffen, T. H. Middleton and their associates. It might be recorded, too, that Sidney Webb, one of the first Development Commissioners, was one of the stoutest supporters of the view that the Commission should foster the development of scientific research into principles rather than confine itself to finding working solutions of current problems.

The book can be cordially commended.

E. J. RusSELL 